\title{
Downregulation of CD73 associates with T cell exhaustion in AML patients
}

\author{
Yaxian Kong ${ }^{1,2,3}$, Bei Jia', Chenchen Zhao', David F. Claxton', Arati Sharma ${ }^{1,4}$, Charyguly Annageldiyev', \\ Joseph S. Fotos ${ }^{5}$, Hui Zeng ${ }^{2}$, Robert F. Paulson ${ }^{6}$, K. Sandeep Prabhu $^{6}$ and Hong Zheng ${ }^{1 *}$ (D)
}

\begin{abstract}
Background: Successful treatment for acute myeloid leukemia (AML) remains challenging. Inhibiting immune checkpoint to enhance anti-tumor response is an attractive strategy for effective leukemia therapeutics. CD73 is a recently recognized immune checkpoint mediator that is highly expressed on tumor cells and stromal cells in tumor microenvironment. The ectonucleotidase activity of CD73 catalyzes AMP to adenosine, which subsequently inhibits anti-tumor immune responses. In this study, we aim to explore the effect of CD73 in AML.

Methods: Peripheral blood samples collected from patients with newly diagnosed AML $(n=27)$ were used in this study. CD73 expression on each immune cell component was examined by flow cytometry. Phenotypic study of CD73expressing $T$ cells and analysis of the correlation between CD73 and other immune checkpoints were performed using flow cytometry-based assays. Functional status of $\mathrm{CD}_{73}{ }^{+}$vs. $\mathrm{CD} 73^{-} \mathrm{T}$ cells was assessed in an in vitro cytokine release assay upon CD3/CD28 antibody stimulation.
\end{abstract}

Results: In contrast to the long recognized immune suppressive effect of CD73-adenosine signaling in tumor tissue, we made a striking observation that in AML, CD73 expression on CD8 T cells associates with an increased immune response. $\mathrm{CD}^{+} 3^{+} \mathrm{CD} 8 \mathrm{~T}$ cells are more functional, whereas $\mathrm{CD} 73^{-} \mathrm{CD} 8 \mathrm{~T}$ cells exhibit features of exhaustion manifested by high expression of inhibitory receptors such as PD-1 and TIGIT, increased intracellular expression of Eomes, reduced capacity of cytokine production, and high susceptibility to apoptosis.

Conclusions: Our data highlight the potential of CD73 as a double-edged sword in anti-leukemia immunity and argue strongly for the combinational treatment by adding immune checkpoint inhibitors to the CD73-targeting approaches.

Keywords: CD73, AML, T cell exhaustion, PD-1, TIGIT

\section{Introduction}

Recent FDA approval of eight novel agents in the last 2 years has significantly expanded options for treatment of acute myeloid leukemia (AML) [1-7]. A variety of additional leukemia therapeutics targeting specific genetic mutations or cellular processes are emerging [8-14]. Despite these exciting advances, successful treatment of AML remains challenging with 5-year survival of only $27.4 \%$ according to the National Cancer Institute (NCI). Novel effective and better tolerated leukemia therapeutics is an urgent unmet need.

\footnotetext{
* Correspondence: hzheng@pennstatehealth.psu.edu

${ }^{1}$ Penn State Hershey Cancer Institute, Penn State University College of

Medicine, Hershey, PA 17033, USA

Full list of author information is available at the end of the article
}

Immunotherapy is promising in cancer treatment. Several immune checkpoint inhibitors, such as antibodies against programmed cell death protein 1 (PD-1) or PD-ligand 1 (PD-L1), have been FDA approved for treating multiple solid tumors and Hodgkin lymphoma [1520]. Multiple studies including ours have demonstrated the involvement of PD-1 and other immune inhibitory pathways in the pathogenesis of leukemia progression [21-31]. Clinical translation of strategies targeting PD-1 in AML treatment is currently under active investigations [32, 33]. In fact, Daver et al. have recently reported a promising result from an early clinical trial treating AML patients with a combination of azacitidine and nivolumab, the first approved PD-1-targeting agent [34]. AML is highly heterogeneous. Identification of additional immune regulatory pathways and understanding their interactions

(C) The Author(s). 2019 Open Access This article is distributed under the terms of the Creative Commons Attribution 4.0 International License (http://creativecommons.org/licenses/by/4.0/), which permits unrestricted use, distribution, and 
with other pathogenesis mechanisms are crucial to develop effective immunotherapy for AML.

CD73 is an ectonucleotidase that is highly expressed on tumor cells and multiple cell components in tumor microenvironment such as stromal cells, endothelial cells, and regulatory T cells (Treg) [35]. The 5'-nucleotidase activity of CD73 on these cells catalyzes AMP to adenosine, a potent suppressor for T cell function [36, 37]. Enrichment of adenosine in tumor environment subsequently inhibits anti-tumor $\mathrm{T}$ cell responses [38-42]. This forms the base for targeting CD73 as optimal immunotherapy of cancer [43-45]. Blockade antibodies against CD73 are currently under active clinical studies for treating solid tumors (NCT03454451, NCT02503774). However, little is known for the effect of CD73 in AML. In order to address this important question, we performed comprehensive phenotypic and functional studies on the CD73-expressing $\mathrm{T}$ cells derived from peripheral blood of a cohort of AML patients $(n=27)$ at initial diagnosis.

\section{Materials and methods Patients}

Peripheral blood samples of AML patients were from the tissue bank maintained by the Penn State Cancer Institute of Penn State University College of Medicine, Hershey, PA. The study was approved by the Institutional Review Board of Penn State University College of Medicine. Full written informed consent was obtained from all patients. Samples from 27 patients diagnosed with AML per WHO classification were used in the study. The average age of patients was 63 years old (range 40-80), and there were 11 males and 16 females. Risk stratification based on cytogenetics was per ELN 2017 [46]. The majority of patients carried intermediate (13 patients) or high risk (10 patients), and only 2 patients were categorized with favorable risk. Samples of 16 healthy volunteers (6 males and 10 females, age $57 \pm$ 8 years, range, $44-70$ years) were obtained as controls.

\section{Immunofluorescence staining and flow cytometric analysis}

For surface staining, peripheral blood mononuclear cells (PBMCs) were incubated with directly conjugated mAbs for $30 \mathrm{~min}$ at $4{ }^{\circ} \mathrm{C}$ and then washed before analysis. Antibodies used were anti-human CD3-BV786 or CD3-APC, CD4-BV711, CD8-APC-H7, CD45RA-AF700, CD95-FITC, CD25 BV510, CD73 PE-CY7, CD11b AF700, CD45 BV786, CD14 BV711, CD56-PE-CF594, CD19-FITC, HLA-DR-PE, CD160-AF488 (BD Biosciences, San Diego, CA, USA), CCR7-BV421, PD-1-PE, 2B4-APC (BioLegend, San Diego, CA, USA), TIGIT-APC (Ebioscience, San Diego, CA, USA), LAG-3-AF700 (R\&D Systems, Minneapolis, MN, USA) antibodies, and corresponding isotype controls. Data acquisition was performed on a LSR Fortessa flow cytometer
(BD Biosciences), and data analysis was performed using FlowJo Software (Tree Star, Ashland, OR, USA).

\section{In vitro stimulation and intracellular staining}

PBMCs were cultured in RPMI-1640 medium (GIBCO, Grand Island, NY, USA) containing 10\% FBS and stimulated with anti-CD3/CD28 $(2 \mu \mathrm{g} / \mathrm{mL}$ and $5 \mu \mathrm{g} / \mathrm{mL}$, Ebioscience), plus Golgiplug (BD Biosciences) for $5 \mathrm{~h}$. The cells were then surface stained with CD3-BV786, CD4-BV711, CD8-APC-H7, CD45RA-AF700, and CCR7-FITC and intracellularly stained with IFN- $\gamma$-PE, TNF- $\alpha$-BV421, or IL-2-APC (BD Biosciences) antibodies. For EOMES staining, PBMCs were intracellularly stained with EOMES-eF610 (BD Biosciences). A Fixable Viability Dye eFluor 506 (Ebioscience) was used to assess cell viability.

\section{In vitro expansion and analysis of leukemia-reactive CD8 T cells}

The experiment protocol was described in our previous published studies [47]. Briefly, purified CD8 T cells derived from PBMCs of AML patients were co-cultured with T2 cells that were pulsed with $10 \mu \mathrm{M} \mathrm{WT1} 1_{126-134}$ peptide, in the presence of $50 \mathrm{IU}$ IL-2 (R\&D system) for 6 days. IL-2 was re-added on day 3. On day $6, \mathrm{CD} 8 \mathrm{~T}$ cells were re-stimulated with the peptides, plus GolgiPlug, for $5 \mathrm{~h}$ and followed by intracellular cytokine staining and flow cytometric analysis.

\section{siRNA transfection}

SMARTpool Accell CD73 siRNA, Accell Non-targeting Pool, and Accell siRNA delivery media were purchased from GE Dharmacon (Lafayette, CO, USA). Control and specific siRNAs were transfected in a 96-well tissue culture plate at a final concentration of $2 \mu \mathrm{M}$ with Accell siRNA delivery media for $72 \mathrm{~h}$. Cells were then stimulated with anti-CD3/CD28 antibodies for $5.5 \mathrm{~h}$ for cytokine functional assay, measured by flow cytometry.

\section{Apoptosis analysis}

PE Annexin V Apoptosis Detection Kit (BD Biosciences) was used for apoptosis assay following the manufacturer's instructions, in combination with markers for $\mathrm{T}$ cells.

\section{Statistical analysis}

Data are expressed as the mean \pm standard deviation (SD). GraphPad 5 (GraphPad Software, La Jolla, CA, USA) or SPSS (IBM Corporation, New York, NY, USA) were used for statistical calculations. The normality of each variable was evaluated using the Kolmogorov-Smirnov test. In cases of normally distributed data, the comparison of variables was performed using unpaired or paired (where specified) two-tailed Student's $t$ tests for unpaired and paired data, respectively. When the data were not normally 
distributed, the comparison of variables was performed with a Mann-Whitney $U$ test or a Wilcoxon matched-pairs signed rank test for unpaired and paired data, respectively. Comparisons of patient characteristics were analyzed using Fisher's exact test (categorical variables) or Wilcoxon rank sum test (continuous variables). To evaluate correlation, Pearson's correlation coefficients were used. For all analyses, $P$ values less than 0.05 were considered statistically significant.

\section{Results}

CD73 is highly expressed on CD8 T cells in peripheral blood from AML patients

To determine which cell components express CD73 in a patient with AML, peripheral blood mononuclear cells (PBMCs) were assessed for CD73 expression by flow cytometry gated on markers for blast (CD45 ${ }^{\text {int }}$, low SSC), Treg $\left(\mathrm{CD} 45^{\mathrm{hi}} \mathrm{CD} 4{ }^{+} \mathrm{CD} 25^{+}\right), \mathrm{CD} 4, \mathrm{CD} 8$, NK $\left(\mathrm{CD} 45^{\mathrm{hi}} \mathrm{CD} 3^{-} \mathrm{CD} 56^{+}\right)$, monocytes $\left(\mathrm{CD} 45^{\mathrm{hi}} \mathrm{CD} 11 \mathrm{~b}^{+} \mathrm{CD} 14^{\mathrm{hi} / \mathrm{low}}\right)$, and dendritic cells (DCs; CD $45^{\text {hi }}{ }^{\mathrm{CD}} 3^{-} \mathrm{CD} 19^{-} \mathrm{CD} 56^{-} \mathrm{CD} 14^{-} \mathrm{HLA}^{-} \mathrm{DR}^{+}$). In contrast to the findings in previous studies of solid tumors that primary tumor or tumor cell lines highly express CD73, we observed minimal CD73 expression on AML blasts (mean frequency $4.75 \pm 6.21$, Fig. 1a, b), whereas the majority of patients express significant level of CD73 on their CD8 T cells (mean frequency $22.26 \pm 13.79$, Fig. 1a, b). There was moderate CD73 expression on monocytes and DCs, while low expression was detected on Treg, CD4 T cells, and NK cells (Fig. 1a, b). This data suggests the involvement of CD73 in CD8 T cell response in AML.

\section{Low CD73 expression on CD8 T cells associates with high} leukemia burden

We then focused our study on CD8 T cells and compared the expression of CD73 in AML $(n=27)$ vs. healthy controls $(n=16)$. Strikingly, CD8 T cells from newly diagnosed AML patients expressed significantly lower frequency of CD73 compared with those from healthy controls ( $P=0.0006$, Fig. 1c). We further assessed the longitudinal samples collected from the same patients at the initial diagnosis and at the time of complete remission (morphologically leukemia free) post treatment. We observed a significant increase of CD73 expression on CD8 $\mathrm{T}$ cells upon achieving complete remission $(P=0.0426$, Fig. 1d). Therefore, low CD73 expression on CD8 T cells associates with high leukemia burden.

\section{CD73 is preferentially expressed on naïve T cells}

We next investigated the phenotypic features of CD8 T cells expressing CD73. Based on the expression of CD45RA and CCR7, T cells can be divided into four subsets: naïve $\mathrm{T}$ cells $\left(\mathrm{T}_{\mathrm{N}} ; \mathrm{CCR} 7^{+} \mathrm{CD} 45 \mathrm{RA} \mathrm{A}^{+}\right)$, central memory $\mathrm{T}$ cells $\left(\mathrm{T}_{\mathrm{CM}} ; \mathrm{CCR} 7^{+} \mathrm{CD} 45 \mathrm{RA}^{-}\right)$, effector memory $\mathrm{T}$ cells $\left(\mathrm{T}_{\mathrm{EM}} ; \mathrm{CCR}^{-} \mathrm{CD}^{-} 5 \mathrm{RA}^{-}\right)$, and terminally differentiated effector cells $\left(\mathrm{T}_{\mathrm{EMRA}} ; \mathrm{CCR} 7^{-} \mathrm{CD} 45 \mathrm{RA}^{+}\right)$. We assessed the expression of CD73 on each subset and observed significantly higher expression of CD73 on $\mathrm{T}_{\mathrm{N}}$, compared to that of $\mathrm{T}_{\mathrm{CM}}, \mathrm{T}_{\mathrm{EM}}$, and $\mathrm{T}_{\mathrm{EMRA}}$, indicating the downregulation of $\mathrm{CD} 73$ in antigen-experienced CD8 cells. This occurred in both AML patients as well as healthy controls. Although there was no difference of CD73 expression on CD8 $\mathrm{T}_{\mathrm{EM}}$ and $\mathrm{T}_{\mathrm{EMRA}}$ cells among healthy controls and AML patients, CD8 $\mathrm{T}_{\mathrm{N}}$ and $\mathrm{T}_{\mathrm{CM}}$ subset from AML patients expressed lower levels of CD73 compared with those in their counterparts from healthy controls (Fig. 2). Of note, CD73 was expressed lowest on $\mathrm{T}_{\text {EMRA }}$, which are considered terminal effector cells with limited functional capacity and high susceptibility to apoptosis, thus more consistent with an exhaustion phenotype. Our data demonstrated that CD73 expression is high on $\mathrm{T}_{\mathrm{N}}$, but low on $\mathrm{T}_{\mathrm{EMRA}}$ CD8 $\mathrm{T}$ cells in AML patients, indicating a phenotypical correlation between downregulation of CD73 and T cell exhaustion.

\section{$\mathrm{CD}^{-}$CD8 T cells from AML patients exhibited a phenotype of exhaustion and over-activation}

To further determine whether lower expression of CD73 on CD8 T cells from AML patients was associated with status of exhaustion, we compared the expression of a number of inhibitory receptors on the $\mathrm{CD}^{2} 3^{+}$vs. $\mathrm{CD}^{-} 3^{-}$ CD8 T cells in PBMCs collected from AML patients. We observed significantly higher expression of PD-1, TIGIT, 2B4, CD160, and LAG-3 on CD73 ${ }^{-}$CD8 $\mathrm{T}$ cells, compared with that on $\mathrm{CD}^{2} 3^{+} \mathrm{CD} 8 \mathrm{~T}$ cells (Fig. 3a-e). Additionally, expression of CD73 was inversely correlated with expression of TIGIT $(r=-0.62, P=0.0012$, Fig. 3g), 2B4 $(r=-0.72, P<0.0001$, Fig. 3h), CD160 $(r=-0.67, P=$ 0.0004, Fig. 3i), and LAG-3 $(r=-0.52, P=0.0088$, Fig. 3j). We did not find any direct correlation between expression of CD73 and PD-1 $(r=-0.18, P=0.4129$, Fig. 3f $)$.

Since $\mathrm{T}$ cell exhaustion is a consequence of over-activation of $\mathrm{T}$ cells caused by high antigenic stimulation, we also analyzed the activation status of $\mathrm{CD}^{-} \mathrm{CD} 8$ $\mathrm{T}$ cells by measuring HLA-DR expression. We observed a significantly higher expression of HLA-DR in CD73- CD8 $\mathrm{T}$ cells compared with that in $\mathrm{CD}^{+} 3^{+} \mathrm{CD} 8 \mathrm{~T}$ cells (Fig. 4a). Consistently, the expression of CD73 was inversely correlated with that of HLA-DR $(r=-0.66, P=0.0016$, Fig. $4 \mathrm{~b})$.

Furthermore, we examined the expression of Eomesodermin (Eomes), a key transcription factor governing $\mathrm{CD}^{+} \mathrm{T}$ cell exhaustion. It has been demonstrated that Eomes $^{\text {hi }} \mathrm{CD} 8 \mathrm{~T}$ cells are terminally exhausted and not able to be reinvigorated by PD-1 blockade. Intracellular Eomes was assessed on PBMCs from patients with newly diagnosed AML. We observed significantly higher expression of Eomes in $\mathrm{CD}^{-} 3^{-} \mathrm{CD} 8 \mathrm{~T}$ cells than in $\mathrm{CD} 73^{+}$ cells $(P<0.0001$, Fig. $4 \mathrm{c})$, suggesting that $\mathrm{CD}^{-} 3^{-} \mathrm{CD} 8 \mathrm{~T}$ cells in AML are more terminally exhausted. 


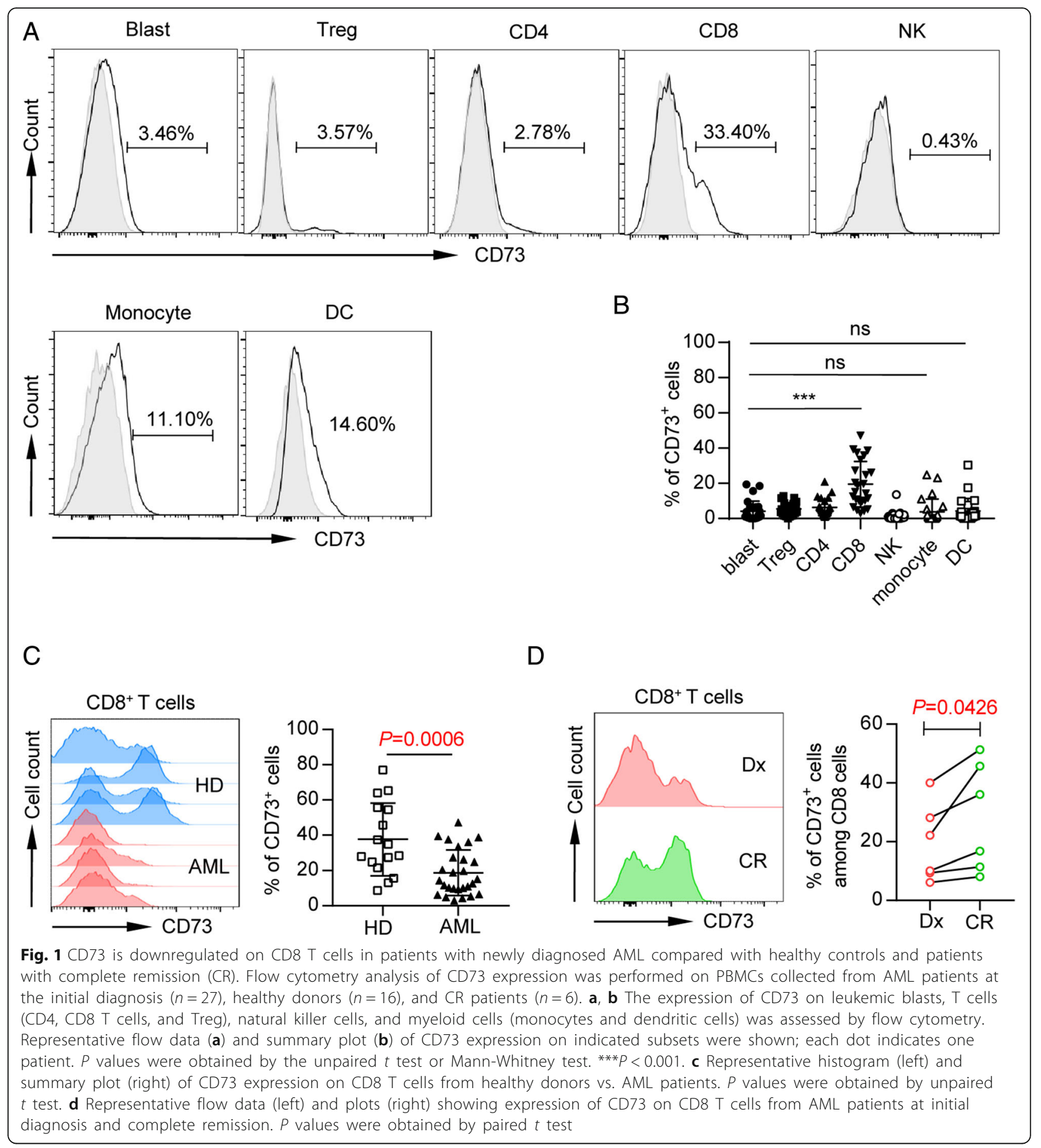

Taken together, our findings demonstrate that in AML patients, $\mathrm{CD}^{-} \mathrm{CD} 8 \mathrm{~T}$ cells expressed high level of co-inhibitory receptors and Eomes. In addition, these cells remained in an over-activated status, therefore are more consistent with an exhausted phenotype.

\section{$\mathrm{CD}^{-} \mathrm{CD} 8 \mathrm{~T}$ cells from AML patients are functionally deficient}

To determine the contribution of CD73 expression to CD8 $\mathrm{T}$ cells' function, we performed an in vitro assay to evaluate intracellular cytokine productions by CD8 T cells upon anti-CD3 and anti-CD28 stimulation. In order 


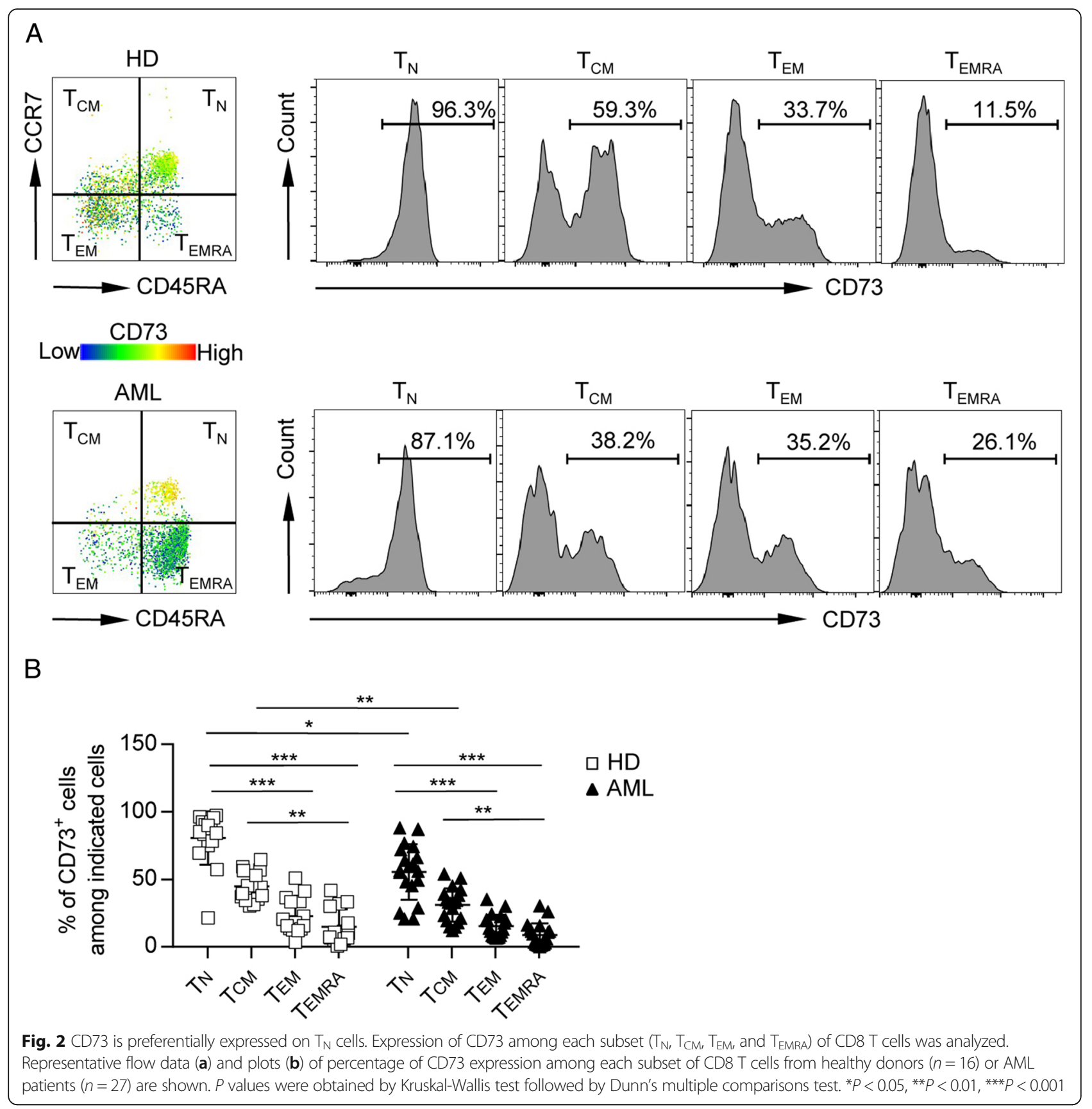

to rule out potential confounding effect of naïve $\mathrm{T}$ cells, which produce minimal cytokines, we specifically analyzed cytokines produced by antigen-experienced cells $\left(\mathrm{T}_{\mathrm{CM}}, \mathrm{T}_{\mathrm{EM}}\right.$, and $\left.\mathrm{T}_{\mathrm{EMRA}}\right)$. We observed a significantly lower release of IL- 2 by $C D 73^{-}$cells compared with that by $\mathrm{CD}^{+} 3^{+}$cells $(P=0.024$, Fig. $5 \mathrm{a})$. There were no significant differences detected between $\mathrm{CD}_{7}{ }^{+}$and $\mathrm{CD}^{-} 3^{-}$ cells in producing TNF- $\alpha$ and IFN- $\gamma$ likely due to limited sample size (Fig. 5a). To further dissect the function of leukemia-reactive $\mathrm{CD}^{-} 3^{-} \mathrm{CD} 8 \mathrm{~T}$ cells, we examined CD8 $\mathrm{T}$ cells for cytokine release in response to WT-1, which is a well-known tumor-associated antigen. CD8 T cells purified from PBMCs of HLA-A*0201 AML patients were co-cultured in vitro with T2 cells (used as antigen-presenting cells) that were pulsed with HLA-A*0201-binding WT-1126-134 peptide. We observed significantly lower production of IL- 2 , TNF- $\alpha$, and IFN- $\gamma$ by $\mathrm{CD}_{73^{-}} \mathrm{CD} 8 \mathrm{~T}$ cells compared to that by $\mathrm{CD}^{+}{ }^{+} \mathrm{CD} 8$ $\mathrm{T}$ cells (Fig. 5b). This important data demonstrate a less anti-leukemia $\mathrm{T}$ cell response in $\mathrm{CD}^{-}{ }^{-} \mathrm{CD} 8 \mathrm{~T}$ cells.

Susceptibility to apoptosis is also a hallmark for functional status of $\mathrm{T}$ cells. $\mathrm{CD}^{-} \mathrm{CD} 8 \mathrm{~T}$ cells from 
A
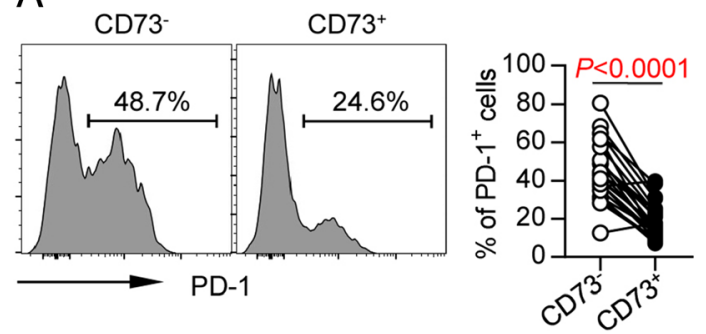

B

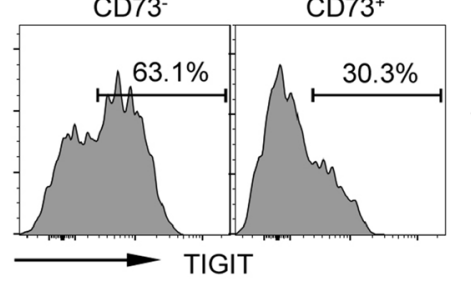

C

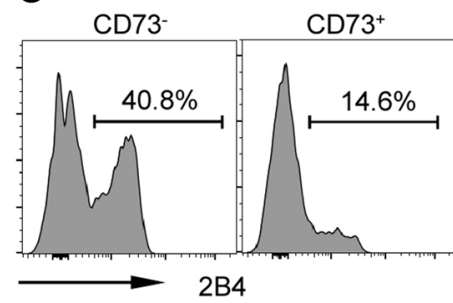

D

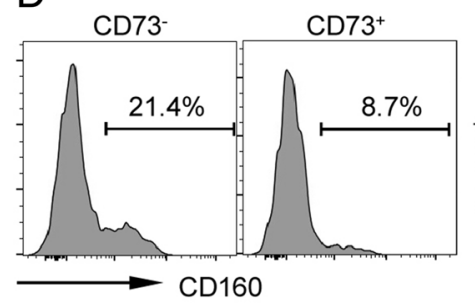

E

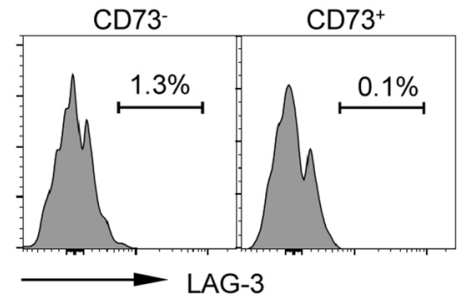

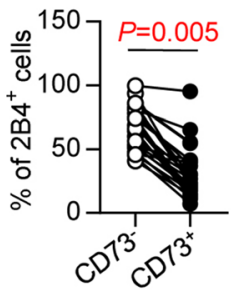
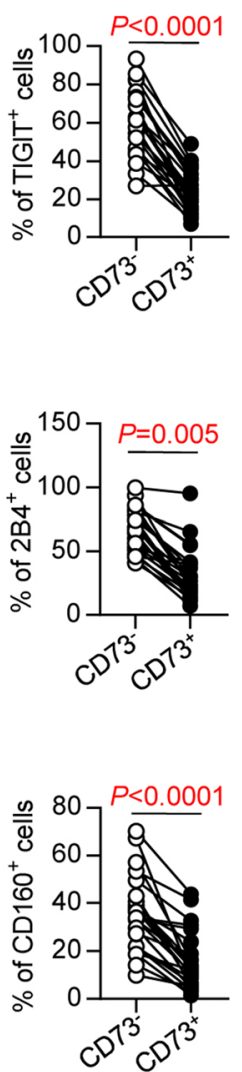

$\mathrm{H}$
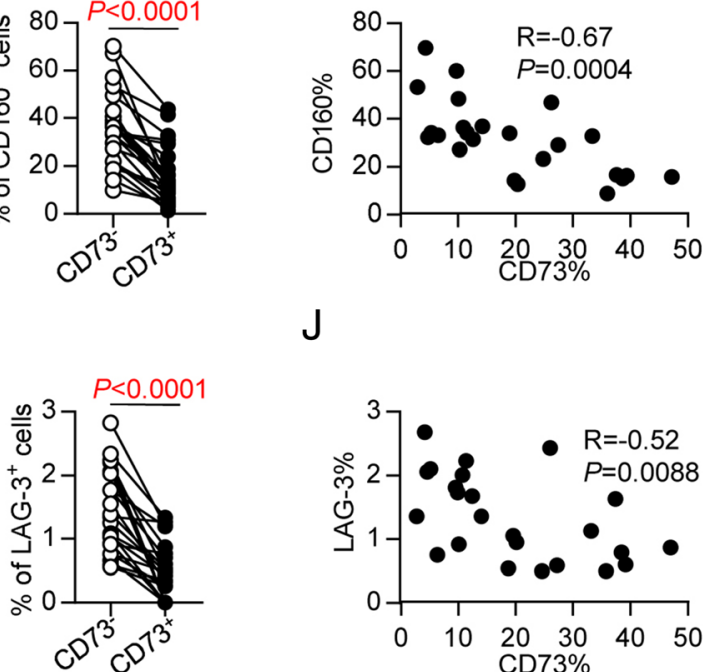

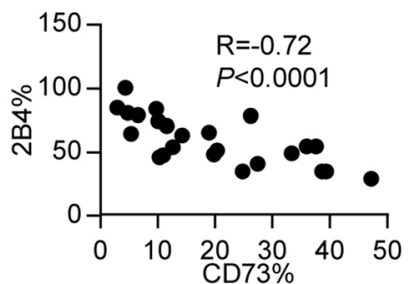

I

J

F

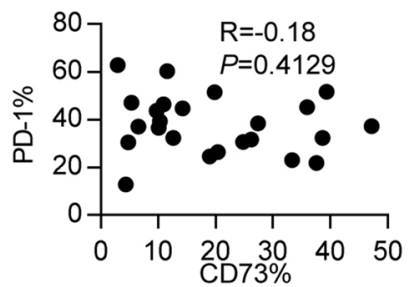

G

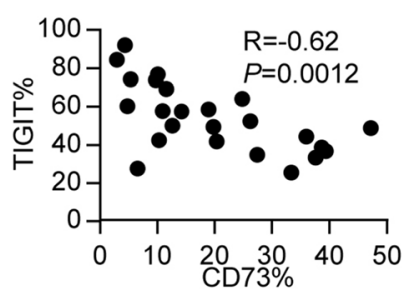

H

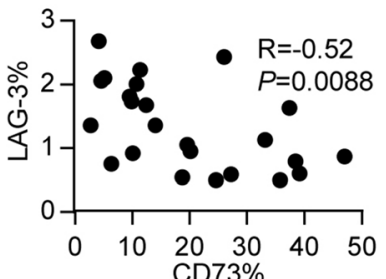

Fig. 3 CD73 expression associates with downregulation of multiple inhibitory receptors. Flow cytometry analysis of expression of PD-1, 2B4, CD160, and LAG3 on CD73- vs. CD73 ${ }^{+}$CD8 ${ }^{+}$T cells from AML patients $(n=25)$. a-e Representative flow data (left) and summary data (right) are shown. $P$ values were obtained by paired $t$ test (PD-1, TIGIT, LAG-3) or Wilcoxon matched-pairs signed rank test (2B4, CD160). $\mathbf{f}-\mathbf{j}$ Correlative analysis of CD73 and expression of above receptors are shown. Pearson's test was used to test for correlations

AML patients showed a trend of higher susceptibility to apoptosis manifested by significantly higher expression of CD95 expression $(P<0.0001$, Fig. 5c).
Interestingly, expression of Annexin $\mathrm{V}$ was comparable between $\mathrm{CD}^{-} 3^{-}$and $\mathrm{CD}^{+} 3^{+} \mathrm{CD} 8 \mathrm{~T}$ cells $(P=$ 0.8725, Fig. 5d). 

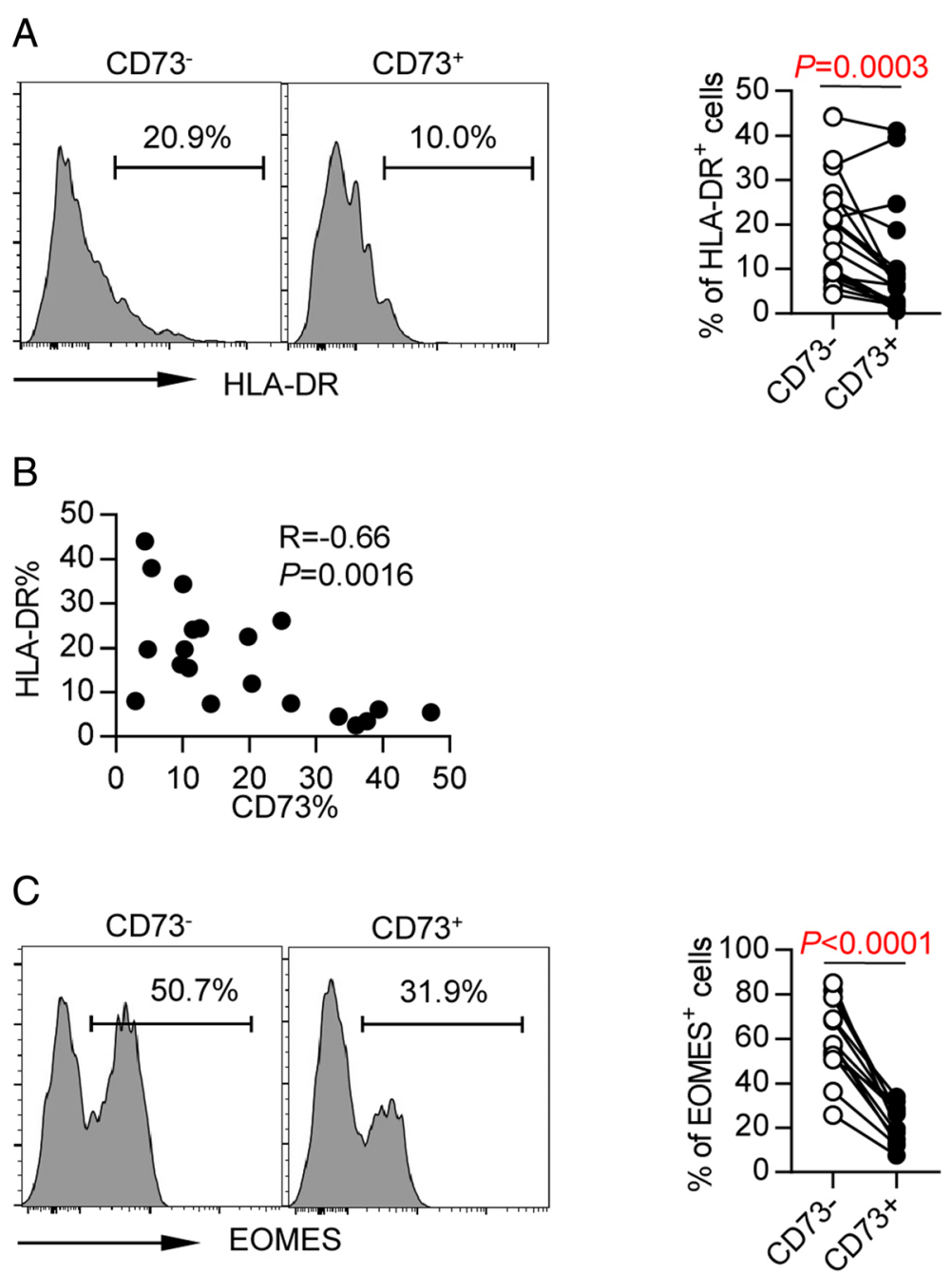

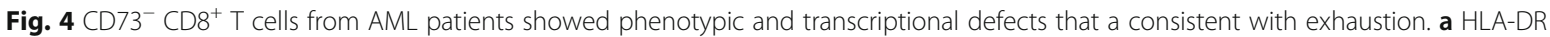
expression on $\mathrm{CD}^{-} 3^{-}$and $\mathrm{CD}_{73}{ }^{+} \mathrm{CD} 8 \mathrm{~T}$ cells from AML patients $(n=19)$. $P$ values were obtained by Wilcoxon matched-pairs signed rank test. $\mathbf{b}$ Correlative analysis of CD73 and HLA-DR is shown. Pearson's test was used to test for correlations. c Intracellular expression of EOMES on CD73 and $\mathrm{CD}_{3}{ }^{+} \mathrm{CD} 8^{+} \mathrm{T}$ cells from AML patients $(n=13)$. $P$ values were obtained by paired $t$ test

Collectively, our findings demonstrate that in AML patients, $\mathrm{CD}^{-}{ }^{-} \mathrm{CD} 8 \mathrm{~T}$ cells expressed high level of immunosuppressive molecules and were less functional, therefore consistent with exhaustion.

\section{Discussion}

Despite the well-known immune suppressive role of the CD73 expression on tumor and stromal cells in tumor microenvironment, literature describing the direct effect of CD73 on T cells is limited. To our knowledge, this is the first study to uncover the important role of CD73 expression on CD8 $\mathrm{T}$ cells in AML. In contrast to the long recognized negative immune regulatory effect of CD73-adenosine signaling in tumor tissue, we made a striking observation that CD73 expression on CD8 T cells associates with an increased immune response.
$\mathrm{CD}^{+}{ }^{+} \mathrm{CD} 8 \mathrm{~T}$ cells are more functional, and high frequency of this subpopulation associates with low disease burden in AML, whereas CD73- $\mathrm{CD} 8 \mathrm{~T}$ cells exhibit features of exhaustion manifested by high expression of inhibitory receptors such as PD-1 and TIGIT, increased intracellular expression of Eomes, and reduced capacity of cytokine production and high susceptibility to apoptosis. Of note, we made an effort to study the effect of knockdown CD73 on CD8 $\mathrm{T}$ cells from AML patients by specific siRNA. CD73 was decreased upon siRNA knockdown; however, it did not significantly alter the cytokine production by CD8 $\mathrm{T}$ cells (data not shown). Therefore, CD73 may regulate $\mathrm{T}$ cell function via an indirect mechanism. Further studies involving multiple immune components in an optimal culture system mimicking tumor microenvironment are warranted to fully address whether 


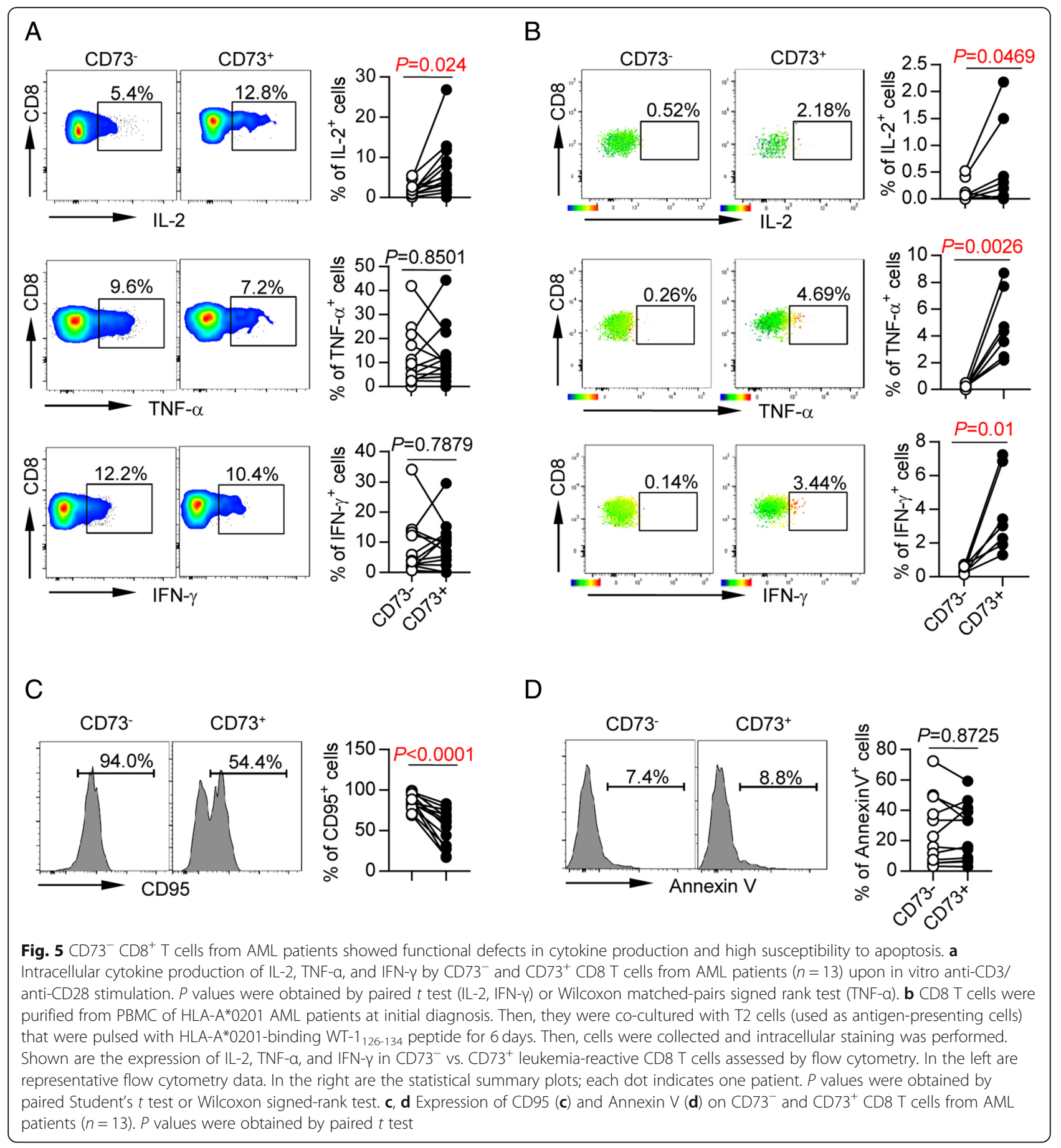

the correlation of CD73 to T cell function is causative. Nevertheless, our data highlight the potential of CD73 as a double-edged sword in anti-leukemia immunity. It provides a rational explanation for the controversial reports in the studies of predictive values of CD73 in clinical outcome for cancer patients. The majority of studies in cancer patients demonstrated an association of elevated CD73 to poor prognosis [48-52]. In contrast, opposite results were reported in other studies in which a correlation of high CD73 expression to a good clinical outcome was observed [53-57]. It is possible that one study mainly detected the CD73 expression on tumor cells, stromal cells, and Treg, while CD73 expression on CD8 T cells was predominantly assessed in the other study. Therefore, understanding the specific distribution pattern of CD73 in each cancer type or disease status is essential for optimal design of clinical studies targeting CD73 for cancer treatment. 
We observed a significantly higher expression of CD73 on naïve $\mathrm{T}$ cells. This is in line with the previous report that $\mathrm{CD} 73$ suppress $\mathrm{T}$ cell differentiation via autocrine adenosine signaling [58]. In addition, it has been showed that $\mathrm{T}$ cells from patients with primary or acquired immunodeficiency display a low CD73 expression and activity [59]. These observations support an important role of CD73 in controlling naïve $\mathrm{T}$ cell homeostasis. Expression of CD73 is rapidly reduced upon $\mathrm{T}$ cell activation and differentiation. In our study of samples from AML patients, CD73-CD8 $\mathrm{T}$ cells are largely antigen-experienced cells and $\mathrm{T}_{\text {EMRA }}$ express the lowest CD73. Together with our data that CD73-CD8 $\mathrm{T}$ cells are less functional, these results indicate an exhaustion pattern of CD73-CD8 T cells.

The results of our study have immense clinical implications. Systemic treatment using blockade antibodies against CD73 is a main approach in the investigational trials targeting CD73-adenosine for cancer control. It is anticipated that inhibition of CD73 on the tumor cells can effectively prevent the release of adenosine, thus enhance anti-tumor immune response and improve clinical outcome. However, our findings that CD73- CD8 T cells express higher frequency of negative receptors such as PD-1, LAG-3, and TIGIT indicate that blocking CD73 may upregulate the inhibitory pathways on CD8 T cells. This could form a potential mechanism of resistance to the CD73-targeting therapies. Our finding is consistent with the report by Tóth et al. that low expression of CD73 on CD8 T cells associates with upregulation of PD- 1 and T cell exhaustion in HIV [60]. These observations argue strongly for the combinational treatment by adding immune checkpoint inhibitors to the CD73-targeting approaches.

\section{Conclusions}

In summary, we made a novel observation that downregulation of CD73 is associated with $\mathrm{T}$ cell exhaustion. CD73CD8 T cells display high expression of inhibitory receptors such as PD-1 and TIGIT, increased intracellular expression of Eomes, reduced capacity of cytokine production, and increased susceptibility to apoptosis. Our data highlight the potential of CD73 as a double-edged sword in anti-leukemia immunity and suggest that combination of CD73-targeting agents and other immune checkpoint inhibitors may represent a promising strategy for optimal leukemia control.

\footnotetext{
Abbreviations

ADP: Adenosine diphosphate; AML: Acute myeloid leukemia; LAG3: Lymphocyte-activation gene 3; PBMCs: Peripheral blood mononuclear cells; PD-1: Programmed cell death protein 1; TIGIT: T cell immunoglobulin and ITIM domain
}

\section{Acknowledgements}

We thank all our patients for their trust, understanding, and willingness to provide their blood samples for our research.

\section{Funding}

This work was supported by the American Society of Hematology (ASH) Scholar Award Grant, the Penn State Cancer Institute (PSCI) and the Penn State University Enhancing Health Initiative, and the Kiesendahl Endowment funding (H.Zheng). R.F.P is funded by USDA-NIFA Hatch project number PEN04581, accession number 1005468

\section{Availability of data and materials}

The datasets used and/or analyzed during the current study are available from the corresponding authors on reasonable request.

\section{Authors' contributions}

YK designed the research study, performed the experiments, analyzed the data, and wrote the manuscript. BJ and CZ collected the samples and performed the experiments. DFC, AS, CA, and JSF acquired the samples, managed the patients, and discussed the data. HZe, RFP, and KSP reviewed the manuscript. HZh conceived the concept, designed the experiments, oversaw the interpretation and presentation of the data, and wrote the manuscript. All authors read and approved the final manuscript.

\section{Ethics approval and consent to participate}

The study was approved by the Institutional Review Board of Penn State University College of Medicine. Full written informed consent was obtained from all patients.

Consent for publication

Not applicable.

\section{Competing interests}

The authors declare that they have no competing interests.

\section{Publisher's Note}

Springer Nature remains neutral with regard to jurisdictional claims in published maps and institutional affiliations.

\section{Author details}

${ }^{1}$ Penn State Hershey Cancer Institute, Penn State University College of Medicine, Hershey, PA 17033, USA. ²Beijing Key Laboratory of Emerging Infectious Diseases, Institute of Infectious Diseases, Beijing Ditan Hospital, Capital Medical University, Beijing 100015, China. ${ }^{3}$ Department of Intensive Care Unit, Affiliated Hospital of Yangzhou University, Yangzhou University, Yangzhou 225000, Jiangsu, China. ${ }^{4}$ Department of Pharmacology, Penn State University College of Medicine, Hershey, PA 17033, USA. ${ }^{5}$ Department of Radiology, Penn State University College of Medicine, Hershey, PA 17033, USA. ${ }^{6}$ Department of Veterinary and Biomedical Sciences, Penn State University College of Agricultural Sciences, University Park, Harrisburg, PA 16802, USA

Received: 11 February 2019 Accepted: 31 March 2019

Published online: 24 April 2019

\section{References}

1. Stone RM, Mandrekar SJ, Sanford BL, Laumann K, Geyer S, Bloomfield CD, Thiede C, Prior TW, Dohner K, Marcucci G, et al. Midostaurin plus chemotherapy for acute myeloid leukemia with a FLT3 mutation. N Engl J Med. 2017;377(5):454-64

2. Stein EM, DiNardo CD, Pollyea DA, Fathi AT, Roboz GJ, Altman JK, Stone RM, DeAngelo DJ, Levine RL, Flinn IW, et al. Enasidenib in mutant IDH2 relapsed or refractory acute myeloid leukemia. Blood. 2017:130(6):722-31.

3. Hills RK, Castaigne S, Appelbaum FR, Delaunay J, Petersdorf S, Othus M, Estey $\mathrm{EH}$, Dombret $\mathrm{H}$, Chevret $\mathrm{S}$, Ifrah $\mathrm{N}$, et al. Addition of gemtuzumab ozogamicin to induction chemotherapy in adult patients with acute myeloid leukaemia: a meta-analysis of individual patient data from randomised controlled trials. Lancet Oncol. 2014;15(9):986-96.

4. DiNardo CD, Stein EM, de Botton S, Roboz GJ, Altman JK, Mims AS, Swords R, Collins RH, Mannis GN, Pollyea DA, et al. Durable remissions with ivosidenib in IDH1-mutated relapsed or refractory AML. N Engl J Med. 2018; 378(25):2386-98.

5. DiNardo CD, Pratz KW, Letai A, Jonas BA, Wei AH, Thirman M, Arellano M, Frattini MG, Kantarjian H, Popovic R, et al. Safety and preliminary efficacy of venetoclax with decitabine or azacitidine in elderly patients with previously 
untreated acute myeloid leukaemia: a non-randomised, open-label, phase 1b study. Lancet Oncol. 2018;19(2):216-28.

6. Lancet JE, Uy GL, Cortes JE, Newell LF, Lin TL, Ritchie EK, Stuart RK, Strickland SA, Hogge D, Solomon SR, et al. CPX-351 (cytarabine and daunorubicin) liposome for injection versus conventional cytarabine plus daunorubicin in older patients with newly diagnosed secondary acute myeloid leukemia. J Clin Oncol. 2018;36(26):2684-92.

7. Yang $X$, Wang J. Precision therapy for acute myeloid leukemia. J Hematol Oncol. 2018;11(1):3.

8. Kantarjian HM, Roboz GJ, Kropf PL, Yee KWL, O'Connell CL, Tibes R, Walsh KJ, Podoltsev NA, Griffiths EA, Jabbour E, et al. Guadecitabine (SGI-110) in treatment-naive patients with acute myeloid leukaemia: phase 2 results from a multicentre, randomised, phase 1/2 trial. Lancet Oncol. 2017;18(10): $1317-26$.

9. Cortes J, Perl AE, Dohner $H$, Kantarjian H, Martinelli G, Kovacsovics T, Rousselot P, Steffen B, Dombret H, Estey E, et al. Quizartinib, an FLT3 inhibitor, as monotherapy in patients with relapsed or refractory acute myeloid leukaemia: an open-label, multicentre, single-arm, phase 2 trial. Lancet Oncol. 2018;19(7):889-903.

10. Wang AY, Weiner $H$, Green $M$, Chang $H$, Fulton $N$, Larson RA, Odenike O, Artz AS, Bishop MR, Godley LA, et al. A phase I study of selinexor in combination with high-dose cytarabine and mitoxantrone for remission induction in patients with acute myeloid leukemia. J Hematol Oncol. 2018;11(1):4

11. Teh TC, Nguyen NY, Moujalled DM, Segal D, Pomilio G, Rijal S, Jabbour A, Cummins K, Lackovic K, Blombery P, et al. Enhancing venetoclax activity in acute myeloid leukemia by co-targeting MCL1. Leukemia. 2018;32(2):303-12.

12. Stein EM, Garcia-Manero G, Rizzieri DA, Tibes R, Berdeja JG, Savona MR, Jongen-Lavrenic M, Altman JK, Thomson B, Blakemore SJ, et al. The DOT1L inhibitor pinometostat reduces $\mathrm{H} 3 \mathrm{~K} 79$ methylation and has modest clinical activity in adult acute leukemia. Blood. 2018;131(24):2661-9.

13. Lian X, Lin YM, Kozono S, Herbert MK, Li X, Yuan X, Guo J, Guo Y, Tang M, Lin J, et al. Pin 1 inhibition exerts potent activity against acute myeloid leukemia through blocking multiple cancer-driving pathways. J Hematol Oncol. 2018;11(1):73.

14. Wu M, Li C, Zhu X. FLT3 inhibitors in acute myeloid leukemia. J Hematol Oncol. 2018;11(1):133.

15. Chen L, Han X. Anti-PD-1/PD-L1 therapy of human cancer: past, present, and future. J Clin Invest. 2015;125(9):3384-91.

16. Topalian SL, Drake CG, Pardoll DM. Immune checkpoint blockade: a common denominator approach to cancer therapy. Cancer Cell. 2015;27(4):450-61.

17. Callahan MK, Postow MA, Wolchok JD. Targeting T cell co-receptors for cancer therapy. Immunity. 2016;44(5):1069-78.

18. Li Z, Song W, Rubinstein M, Liu D. Recent updates in cancer immunotherapy: a comprehensive review and perspective of the 2018 China Cancer Immunotherapy Workshop in Beijing. J Hematol Oncol. 2018;11(1):142.

19. Sharma P, Hu-Lieskovan S, Wargo JA, Ribas A. Primary, adaptive, and acquired resistance to cancer immunotherapy. Cell. 2017;168(4):707-23.

20. Wang J, Yuan R, Song W, Sun J, Liu D, Li Z. PD-1, PD-L1 (B7-H1) and tumorsite immune modulation therapy: the historical perspective. J Hematol Oncol. 2017;10(1):34

21. Zhang L, Gajewski TF, Kline J. PD-1/PD-L1 interactions inhibit antitumor immune responses in a murine acute myeloid leukemia model. Blood. 2009; 114(8):1545-52.

22. Norde WJ, Maas F, Hobo W, Korman A, Quigley M, Kester MG, Hebeda K, Falkenburg JH, Schaap N, de Witte TM, et al. PD-1/PD-L1 interactions contribute to functional T-cell impairment in patients who relapse with cancer after allogeneic stem cell transplantation. Cancer Res. 2011;71(15):5111-22.

23. Zhou Q, Munger ME, Veenstra RG, Weigel BJ, Hirashima M, Munn DH, Murphy WJ, Azuma M, Anderson AC, Kuchroo VK, et al. Coexpression of Tim-3 and PD-1 identifies a CD8+ T-cell exhaustion phenotype in mice with disseminated acute myelogenous leukemia. Blood. 2011;117(17):4501-10.

24. Kong Y, Zhang J, Claxton DF, Ehmann WC, Rybka WB, Zhu L, Zeng H, Schell TD, Zheng H. PD-1(hi)TIM-3(+) T cells associate with and predict leukemia relapse in AML patients post allogeneic stem cell transplantation. Blood Cancer J. 2015;5:e330.

25. Kronig H, Kremmler L, Haller B, Englert C, Peschel C, Andreesen R, Blank CU. Interferon-induced programmed death-ligand 1 (PD-L1/B7-H1) expression increases on human acute myeloid leukemia blast cells during treatment. Eur J Haematol. 2014;92(3):195-203.

26. Kong Y, Zhu L, Schell TD, Zhang J, Claxton DF, Ehmann WC, Rybka WB, George MR, Zeng H, Zheng $\mathrm{H}$. T-cell immunoglobulin and ITIM domain
(TIGIT) associates with CD8+ T-cell exhaustion and poor clinical outcome in AML patients. Clin Cancer Res. 2016;22(12):3057-66.

27. Zhu L, Kong Y, Zhang J, Claxton DF, Ehmann WC, Rybka WB, Palmisiano ND, Wang $M$, Jia B, Bayerl M, et al: Blimp-1 impairs T cell function via upregulation of TIGIT and PD-1 in patients with acute myeloid leukemia. J Hematol Oncol. 2017;10(1):124.

28. Jia B, Wang L, Claxton DF, Ehmann WC, Rybka WB, Mineishi S, Rizvi S, Shike $\mathrm{H}$, Bayerl M, Schell TD, et al. Bone marrow CD8 T cells express high frequency of PD-1 and exhibit reduced anti-leukemia response in newly diagnosed AML patients. Blood Cancer J. 2018;8(3):34.

29. Im A, Pavletic SZ. Immunotherapy in hematologic malignancies: past, present, and future. J Hematol Oncol. 2017;10(1):94.

30. Hutten TJA, Norde WJ, Woestenenk R, Wang RC, Maas F, Kester M, Falkenburg JHF, Berglund S, Luznik L, Jansen JH, et al. Increased coexpression of PD-1, TIGIT, and KLRG-1 on tumor-reactive CD8(+) T cells during relapse after allogeneic stem cell transplantation. Biol Blood Marrow Transplant. 2018;24(4):666-77.

31. Williams P, Basu S, Garcia-Manero G, Hourigan CS, Oetjen KA, Cortes JE, Ravandi F, Jabbour EJ, Al-Hamal Z, Konopleva M et al: The distribution of Tcell subsets and the expression of immune checkpoint receptors and ligands in patients with newly diagnosed and relapsed acute myeloid leukemia. 2018.

32. Lichtenegger FS, Krupka C, Haubner S, Kohnke T, Subklewe M. Recent developments in immunotherapy of acute myeloid leukemia. J Hematol Oncol. 2017;10(1):142.

33. Ok CY, Young KH. Checkpoint inhibitors in hematological malignancies. J Hematol Oncol. 2017;10(1):103.

34. Daver N, Garcia-Manero G, Basu S, Boddu PC, Alfayez M, Cortes JE, Konopleva M, Ravandi-Kashani F, Jabbour E, Kadia TM et al: Efficacy, safety, and biomarkers of response to azacitidine and nivolumab in relapsed/refractory acute myeloid leukemia: a non-randomized, openlabel, phase 2 study. 2018.

35. Allard B, Longhi MS, Robson SC, Stagg J. The ectonucleotidases CD39 and CD73: novel checkpoint inhibitor targets. Immunol Rev. 2017;276(1):121-44.

36. Beavis PA, Stagg J, Darcy PK, Smyth MJ. CD73: a potent suppressor of antitumor immune responses. Trends Immunol. 2012;33(5):231-7.

37. Zimmermann $\mathrm{H}$, Zebisch $\mathrm{M}$, Strater $\mathrm{N}$. Cellular function and molecular structure of ecto-nucleotidases. Purinergic Signal. 2012;8(3):437-502.

38. Cekic C, Sag D, Day YJ, Linden J. Extracellular adenosine regulates naive T cell development and peripheral maintenance. J Exp Med. 2013; 210(12):2693-706

39. Hausler SF, Montalban del Barrio I, Strohschein J, Chandran PA, Engel JB, Honig A, Ossadnik M, Horn E, Fischer B, Krockenberger M, et al. Ectonucleotidases CD39 and CD73 on OvCA cells are potent adenosinegenerating enzymes responsible for adenosine receptor 2A-dependent suppression of T cell function and NK cell cytotoxicity. Cancer Immunol Immunother. 2011;60(10):1405-18.

40. Jin D, Fan J, Wang L, Thompson LF, Liu A, Daniel BJ, Shin T, Curiel TJ, Zhang B. CD73 on tumor cells impairs antitumor T-cell responses: a novel mechanism of tumor-induced immune suppression. Cancer Res. 2010;70(6):2245-55

41. Novitskiy SV, Ryzhov S, Zaynagetdinov R, Goldstein AE, Huang Y, Tikhomirov OY, Blackburn MR, Biaggioni I, Carbone DP, Feoktistov I, et al. Adenosine receptors in regulation of dendritic cell differentiation and function. Blood. 2008;112(5):1822-31.

42. Ryzhov S, Novitskiy SV, Goldstein AE, Biktasova A, Blackburn MR, Biaggioni I, Dikov MM, Feoktistov I. Adenosinergic regulation of the expansion and immunosuppressive activity of CD11b+Gr1+ cells. J Immunol (Baltimore, Md: 1950). 2011;187(11):6120-9.

43. Antonioli L, Novitskiy SV, Sachsenmeier KF, Fornai M, Blandizzi C, Hasko G. Switching off CD73: a way to boost the activity of conventional and targeted antineoplastic therapies. Drug Discov Today. 2017;22(11):1686-96.

44. Antonioli L, Yegutkin GG, Pacher P, Blandizzi C, Hasko G. Anti-CD73 in cancer immunotherapy: awakening new opportunities. Trends Cancer. 2016;2(2):95-109.

45. Hay CM, Sult E, Huang Q, Mulgrew K, Fuhrmann SR, McGlinchey KA, Hammond SA, Rothstein R, Rios-Doria J, Poon E, et al. Targeting CD73 in the tumor microenvironment with MEDI9447. Oncoimmunology. 2016;5(8):e1208875.

46. Dohner H, Estey E, Grimwade D, Amadori S, Appelbaum FR, Buchner T, Dombret $H$, Ebert BL, Fenaux P, Larson RA, et al. Diagnosis and 
management of AML in adults: 2017 ELN recommendations from an international expert panel. Blood. 2017;129(4):424-47.

47. Jia B, Zhao C, Rakszawski KL, Claxton DF, Ehmann WC, Rybka WB, Mineishi S, Wang M, Shike H, Bayerl MG, et al. Eomes+T-betlow CD8+ T cells are functionally impaired and are associated with poor clinical outcome in patients with acute myeloid leukemia Cancer Res. 2019;79(7):1635-45.

48. Gaudreau PO, Allard B, Turcotte M, Stagg J. CD73-adenosine reduces immune responses and survival in ovarian cancer patients. Oncoimmunology. 2016;5(5):e1127496.

49. Inoue $\mathrm{Y}$, Yoshimura K, Kurabe N, Kahyo T, Kawase A, Tanahashi M, Ogawa H, Inui N, Funai K, Shinmura K, et al. Prognostic impact of CD73 and A2A adenosine receptor expression in non-small-cell lung cancer. Oncotarget. 2017;8(5):8738-51.

50. Leclerc BG, Charlebois R, Chouinard G, Allard B, Pommey S, Saad F, Stagg J. $\mathrm{CD} 73$ expression is an independent prognostic factor in prostate cancer. Clin Cancer Res. 2016;22(1):158-66.

51. Turcotte M, Spring K, Pommey S, Chouinard G, Cousineau I, George J, Chen GM, Gendoo DM, Haibe-Kains B, Karn T, et al. CD73 is associated with poor prognosis in high-grade serous ovarian cancer. Cancer Res. 2015;75(21):4494-503.

52. Wu XR, He XS, Chen YF, Yuan RX, Zeng Y, Lian L, Zou YF, Lan N, Wu XJ, Lan P. High expression of CD73 as a poor prognostic biomarker in human colorectal cancer. J Surg Oncol. 2012;106(2):130-7.

53. Bowser JL, Blackburn MR, Shipley GL, Molina JG, Dunner K Jr, Broaddus RR. Loss of CD73-mediated actin polymerization promotes endometrial tumor progression. J Clin Invest. 2016;126(1):220-38.

54. Cushman SM, Jiang C, Hatch AJ, Shterev I, Sibley AB, Niedzwiecki D, Venook AP, Owzar K, Hurwitz HI, Nixon AB. Gene expression markers of efficacy and resistance to cetuximab treatment in metastatic colorectal cancer: results from CALGB 80203 (Alliance). Clin Cancer Res. 2015;21(5):1078-86.

55. Oh HK, Sin Jl, Choi J, Park SH, Lee TS, Choi YS. Overexpression of CD73 in epithelial ovarian carcinoma is associated with better prognosis, lower stage, better differentiation and lower regulatory T cell infiltration. J Gynecol Oncol. 2012;23(4):274-81.

56. Supernat A, Markiewicz A, Welnicka-Jaskiewicz M, Seroczynska B, Skokowski J, Sejda A, Szade J, Czapiewski P, Biernat W, Zaczek A. CD73 expression as a potential marker of good prognosis in breast carcinoma. Appl Immunohistochem Mol Morphol. 2012;20(2):103-7.

57. Wettstein MS, Buser L, Hermanns T, Roudnicky F, Eberli D, Baumeister P, Sulser T, Wild P, Poyet C. CD73 predicts favorable prognosis in patients with nonmuscle-invasive urothelial bladder cancer. Dis Markers. 2015;2015:785461.

58. Bono MR, Fernandez D, Flores-Santibanez F, Rosemblatt M, Sauma D. CD73 and CD39 ectonucleotidases in T cell differentiation: beyond immunosuppression. FEBS Lett. 2015;589(22):3454-60.

59. Marashi SM, Raeiszadeh M, Workman S, Rahbar A, Soderberg-Naucler C, Klenerman P, Chee R, Webster AD, Milne RS, Emery VC. Inflammation in common variable immunodeficiency is associated with a distinct $\mathrm{CD} 8(+)$ response to cytomegalovirus. J Allergy Clin Immunol. 2011;127(6):1385-93 e1384

60. Toth I, Le AQ, Hartjen P, Thomssen A, Matzat V, Lehmann C, Scheurich C, Beisel C, Busch P, Degen O, et al. Decreased frequency of CD73+CD8+ T cells of HIV-infected patients correlates with immune activation and T cell exhaustion. J Leukoc Biol. 2013;94(4):551-61.

\section{Ready to submit your research? Choose BMC and benefit from:}

- fast, convenient online submission

- thorough peer review by experienced researchers in your field

- rapid publication on acceptance

- support for research data, including large and complex data types

- gold Open Access which fosters wider collaboration and increased citations

- maximum visibility for your research: over $100 \mathrm{M}$ website views per year

At BMC, research is always in progress.

Learn more biomedcentral.com/submissions 